\title{
Dykare och dynamit
}

Löjtnanten Anton Ludvig Fahnehjelm (I807-I875), sedermera major, anses vara den som introducerade tungdykardräkten i Sverige, vilket ska ha skett redan I839. Det är osäkert om Fahnehjelm gjorde nedstigningar på Riksäpplet, däremot så dök han på det samtida skeppet Nyckeln, som ligger vrak i Kalmarsund, och förmodligen även på Vasa i Stockholms hamn (Cederlund 2006:II4-I2I; 20I2:I2).

Från I863 finns dock pålitliga rapporter om att dykare igen varit nere även på Riksäpplet. Det mest anmärkningsvärda fyndet vid detta tillfälle anses vara ett av skeppets ankare (Cederlund 1983:39). Fem år senare, I868, genomförde Stockholms dykeribolag under ledning av Carl Ludvig Santesson (1843-1894) ytterligare dyk på vraket. I en beskrivning nedtecknad i samband med händelsen får vi veta att "dykarne voro inne i linieskeppets kokhus eller kabyss, hvarest spiseln murad af tegel, ännu var i behåll” samt att "uti ett annat förvaringsrum sutto ännu efter nära 200 år block upphängda på sina platser" (citat i Cederlund 2012:I2).

Beskrivningen ska dock inte läsas som att skrovet var helt och sammanhängande. De klumpiga tungdykarna kunde inte gärna ha klivit in med blyskorna i skeppets kabyss om skrovet varit intakt.

Dykningarna på Riksäpplet fick snart en kommersiell karaktär sedan "hufvudstadens största trähandlare" fått undersöka ekvirke som lyfts från skeppet. Det ansågs vara av utmärkt kvalitet. I en samtida beskrivning menar man att det i vissa delar överträffade mahogny och behöll en vacker svart färg även sedan det torkat. Trähandlaren gjorde därefter affär med dykeribolaget om köp av allt ekvirke som kunde bärgas. Inte mindre än I ooo kubikfot svartek ska Stockholms dykeribolag ha fått loss och bärgat från Riksäpplet. Av virket tillverkade ett par av huvudstadens större snickare en del vackra möbler (Cederlund 20I2:19).

Stockholms dykeribolag anlitades för stora arbeten i Stockholms hamn, bland annat för att undanröja grundklackar och vrak (ibid.: 2I-22). 
Det säger sig självt att bolaget var väl förtroget med dykeritekniken, men det låg även i framkant med andra innovationer som hör tiden till.

Alfred Nobel är något av en ikon för den innovations- och entreprenörsanda som framhålls i berättelsen om I80o-talets industrialisering. Nitroglycerinet och dynamiten kom att avsevärt effektivisera de flesta former av sprängarbeten och underlättade allt från gruvbrytning till tunnelbyggen. En avgjord fördel med det nya sprängämnet var att det var mer lämpat för detonationer under vatten (Larsson 2010). Läderrören och svartkrutsbomberna som Liberton varit hänvisad till framstod snart som hopplöst obsoleta.

En reporter från Gefleposten som sänts till Dalarö för att berätta om bärgningarna vittnar dock om att entreprenörerna hade en del problem att "få det nya krutet att tända" (Gefleposten I868-05-28). En uppgift som felaktigt satts i samband med Olschanskis bärgningsverksamhet först 70 år senare (se nedan), men som snarare härrör från arbetena på ı80o-talet, är att ramar av läkt spikades ihop på vilka dynamitgubbar monterades. Ramarna sänktes därefter ner mot vraket för att sprängas (jfr Hamilton 1957:170).

ı860-talets bärgningar syftade till att lyfta virke som genom försäljning kunde omvandlas till reda pengar. Intresset för svarteken tycks bottna i ett affektionsvärde som egentligen påminner ganska mycket om intresset för metall från trofékanoner som förekom inom I6oo-talets amiralitet. Svartnad ek är ett material som bär på en erfarenhet och snickeriarbetena försågs inte sällan med inskriptioner som avslöjade materialets ursprung, eller åtföljdes av ett äkthetsintyg.

På ett bokstöd som tillverkats av Riksäpplets virke och som finns i Nordiska museets samlingar (inventarienummer NM 0079837), har ursprunget deklarerats genom ett skulpterat äpple flankerat av I676 och I868, årtal som markerar perioden då virket lagrats på botten. Bokstödet tillverkades av ornamentbildhuggaren Henrik Nerpin (1834-1908), som bland annat anförtroddes arbeten på Stockholms slott.

Det var inte bara småsaker som tillverkades av det bärgade ekvirket. När greve Rudolf Adlersparre beställde och själv bekostade Österviks kapell utanför Kristinehamn, förfärdigades dörrarna av det exklusiva sjödränkta materialet (Toijer 1958:65). Ett annat parti virke ska ha sålts till Evangelistiska fosterlandsstiftelsens utlandsmission ( $A B$ I92I-09o9), men det är obekant hur de använde sig av virket.

Även om Stockholms dykeribolags insatser främst hade ekonomiska förtecken så framskymtar ändå en viss historisk nyfikenhet på och 
häpnad över det gamla skeppet och de fynd som fanns däri. Samtidigt som sprängningen kan tyckas ohämmad och brutal så reflekterar dykarna faktiskt något över vad de sett. Vi får således veta att de påträffat (citat i Cederlund 2012:18-19):

Skråkappor, bestående af träcylindrar hvaruti de mindre kulorna eller skrået blifvit löst lagda ibland krutet, äfvensom träcylindrar fyllda endast med krut [så kallade krutkoger, se kapitel 6]; vantjungfrur, hvaruti delar av talgrepet ännu var kvarsittande; delar af lavetter; stycken av tåg, kablar, bly- och kopparplåt, järnkulor, kanoner av gjutjärn $\mathrm{mm}$.

De gjutjärnskanoner som betraktades som värdelösa på I60o-talet efter att de legat under vatten blev plötsligt intressanta. Men inte som skjutvapen utan i egenskap av antikviteter. År I867 berättas om ytterligare ett ankare som bärgats och förts till Stockholm, där det ställts upp för allmän beskådan. Samma år lyftes tre kanoner vilka flyttades till vattnet utanför Jutholmen där dykeribolaget alltså haft en undervattensdepå. Först 1870 lyftes de upp ur vattnet och transporterades till Stockholm. Elva år senare ställdes de ut på dåvarande Nordiska museet på Drottninggatan för att I886 flyttas till Skansen (fig. 4.I), där de bland annat kom att användas som rekvisita i samband med iscensättanden av karolinernas läger (Cederlund 1983a:39).

Mycket talar för att dykeribolaget lämnade en del fynd på botten utanför Jutholmen. Två eldrör har nämligen bärgats från området under sen tid. Eftersom de påträffades på en i övrigt tom sjöbotten utan vare sig registrerade skeppsvrak eller andra lagskyddade fornlämningar i närheten så kom de rent juridiskt att betecknas som "lösfynd", och kanonerna tillföll upphittarna. Kanonerna visar stora likheter med de eldrör som helt säkert bärgats från Riksäpplet och brännaren Jägaren. De breda banden liksom formen på den så kallade trumfen - dekorationen runt eldrörets mynning - är väldigt karaktäristiska.

Hazelius kanoner förblev i Nordiska museets ägo fram till 2012 då de auktionerades ut och köptes av en privat samlare. De finns nu att beskåda vid Ryttmästarbostället utanför Skövde.

Utöver de tre kanonerna och de båda ankarna bärgade Stockholms dykeribolag även ett antal mindre fynd av trä. Nordiska museet har bland annat en fragmentarisk ansättarkolv, det vill säga änden av en laddstake för kanon, i sina samlingar samt ett stånglod (inventarie- 


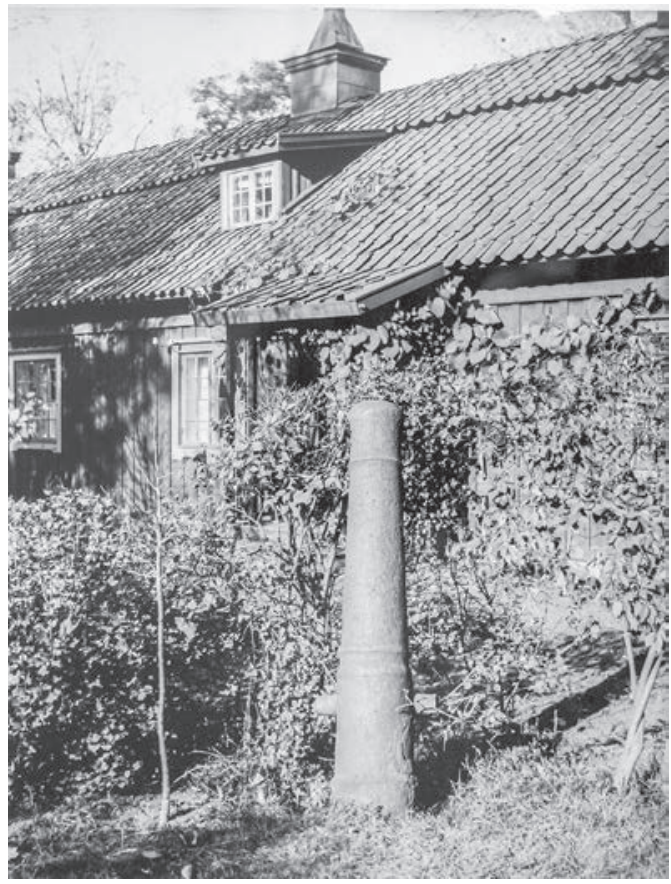

Fig. 4.1. En av de kanoner som Arthur Hazelius köpte från Stockholms dykeribolag sedan den bärgats från Riksäpplet på 1860-talet. Här är den utställd på Skansen (SMM).

nummer NM4378 respektive 4382). Enligt museets liggare är de en gåva från tenngjutaren Nils Abraham Santesson. Denne var far till Carl Santesson som var ägare till Stockholms dykeribolag (Cederlund 20I2:20-2I).

Även Upplandsmuseet förvarar en träbit från Riksäpplet. En påskrift på en fragmentarisk papperslapp gör gällande att det rör sig om "[e]tt styck af Fregatten Äp[plet] som sjönk utanför Da[larö] Skans den 5 Ju[ni I676] [...] till Uppsala [...] Lundeberg 3I Mars I8[oläsligt]" (Upplandsmuseets inventarienummer UMoor87). Träbiten var en gåva till museet från syssloman Sixten Lundeberg.

Efter 1870 tycks intresset för att bärga ytterligare saker från Riksäpplet ha avtagit. Kanske var marknaden för svartnat ekvirke mättad? Tullverksamheten och flottans närvaro på Dalarö avtog så småningom. När ångbåtarna under I80o-talet gjorde skärgården tillgänglig för huvudstadens mer välbärgade societet kom Dalarö att utvecklas till ett attraktivt rekreationsområde och en badort för storstadens bättre 
bemedlade (se t.ex. Eklund 2005). Den dråpliga historien om skeppet Riksäpplet torde dock alltjämt ha gjort sig påmind för dem som passerade genom farleden förbi Äppelskäret. För dem som tog ångbåten till sommarnöjet eller tog in på pensionaten trycktes olika guidetexter och områdesbeskrivningar, i vilka det gamla örlogsfartyget skymtar förbi. "[D] et lilla skäret Äpplet [...] så kalladt efter det linieskepp, som under Carl den Elftes tid sjönk der”, kunde man läsa i Svenska Familj-Journalen (band I, I87I:I50). Man kan nästan föreställa sig hur societeten rodde omkring i vattnen runt Dalarö och berättade dråpliga historier och skrönor om vad som lurade nere i djupet från Karl XI:s tid.

Förnyade bärgningsinsatser företogs av Aktiebolaget Stammen I9I 4. Det sökte utan framgång efter kanoner. Det är osäkert vad dykarna bärgade. Enligt en obekräftad uppgift ska Stammens dykningar ha genomförts med klocka (SvD I92I-09-20; Randall 2013:III).

\section{Olschanski, kanonerna och svarteken}

De som kanske framför allt förknippas med dykningar och bärgningsarbeten på Riksäpplet är bröderna Simon och Leonard från Dykeriaktiebolaget Olschanski. De får ofta bära huvudansvaret för vrakets sargade tillstånd (se t.ex. Hamilton 1957:170; Franzén 1985:13; Smirnov 2002:98-99). Lorelei Randall (2013) har gjort en ingående studie av dykeribolaget och den del av familjen Olschanskis verksamhet som har att göra med sjunkna skepp, och framställningen här bygger i stor utsträckning på hennes arbete. Sett i sitt sammanhang framstår Olschanskis bidrag till ödeläggelsen som tämligen begränsat.

Olschanskis var en judisk familj som flyttade till Sverige i873. Runt sekelskiftet 1900 grundade Rafael Olschanski (1846-1917) en dykerioch bärgningsfirma och verksamheten inriktades på att köpa havererade och sjunkna fartyg som bärgades och såldes som skrot. Efter Rafaels död övertogs verksamheten av hans söner, Simon och Leonard. Ett antal förlista och grundstötta fartyg bärgades som skrot genom deras försorg, däribland marinens kryssare HMS Claes Uggla, som alltså uppkallats efter den välbekante sjöhjälten. Kryssaren strandade vid Ullånger utanför Härnösand I9I7 och blev vrak (Randall 20I3:5). Att skrotbärgarfirman kom att ändra inriktning och fokusera på historiska vrak har inte alls att göra med amiral Uggla utan bottnar i flera omständigheter.

I slutet av oktober I9I9 grundstötte ångaren Gaude vid Vikstens fyr i Stockholms södra skärgård. Fartyget var på väg till Finland lastat 
med vapen, ammunition och ett nedmonterat flygplan. Neptunbolaget var engagerade i bärgningsarbetet så länge den havererade ångaren stod kvar på grundet. När skrovet så småningom kasade ner utmed undervattensberget och lade sig tillrätta på djupare vatten, blev Gaude ett fall för Olschanskis. Från vraket bärgades 435 Mauser $8 \mathrm{~mm}$-gevär som omhändertogs av tullen i Nynäshamn för vidare transport med plomberade godsvagnar till Stockholm (Randall 2013:I0).

En fiskare hade upplåtit en del av sin mark till upplag för det skrot som Olschanskis lyfte från Gaude. Genom att utöva sitt yrke i vattnen runt Viksten hade han skaffat sig goda kunskaper om vattnets och sjöbottens beskaffenhet. Erfarenheterna av så kallade fastnor var dyrköpta och på ett ställe hade det kostat en dragg. När nu Olschanskis dykare fanns på området hörde han sig för om de inte kunde gå ner och titta efter. Enligt fiskarens vittnesmål var dykaren snart uppe igen och meddelade att han funnit ett vrak från tiden för Kristi födelse (Franzén I985:I2-I3; Randall 20I6:I3). Vid nedstigningen hade han påträffat bronskanoner och ett tidigare okänt gammalt skeppsvrak. Professor Nils Ahnlund kunde senare reda ut att det var resterna efter skeppet Riksnyckeln, som förlist år 1628 och inte ska förväxlas med Nyckeln som var samtida med Riksäpplet och förliste utanför Kalmar år I679.

Under 1920 bärgade Olschanski totalt sju bronskanoner från Riksnyckeln och erhöll 50 ooo kronor från staten (Cederlund 1983:4I; 20I2:39-42; Randall 2013:I6). Det var en ansenlig summa pengar vilket gjorde kanonbärgning till en betydligt mer lukrativ verksamhet än den gängse skrotbärgningen. Framgången gav Olschanskis blodad tand och de historiska vraken framstod nu som tilltalande alternativ framför de havererade ångarna, inte minst som priserna på järnskrot var fallande vid denna tid. Att bärga haverister framstod inte längre som lönsamt och Olschanski såg sig om efter ett annat historiskt vrak att sätta tänderna i. Valet föll på Riksäpplet.

Aktiebolaget $S$. Olschanski ansökte hos länsstyrelsen om ensamrätt till bärgning av Riksäpplet, vilket också beviljades. Det skulle dröja fram till 1967 innan skeppsvrak betraktades som fornlämningar i juridisk mening och blev skyddade enligt kulturminneslagen. Men även om det gamla krigsfartyget vid tidpunkten inte var en lagskyddad fornlämning så fanns ett intresse för att i någon mån bevara vrak, eller åtminstone delar av dem, till eftervärlden. Förhållandet illustreras av en skrivelse från Kungl. Maj:t till Marinförvaltningen. I brevet, som är undertecknat av Gustav V och Per Albin Hansson, föreslås att två lämpliga personer ska 


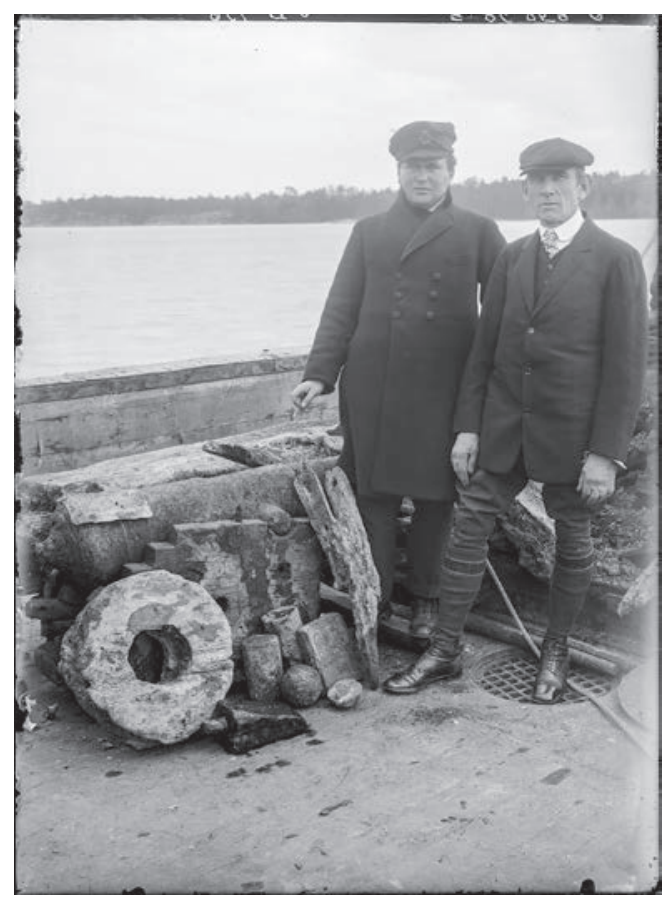

Fig. 4.2. Leonard Olschanski (1882-1943) poserar tillsammans med Lenny Stackell (1875-1957) vid föremål som lyfts från Riksäpplet 1921. Järnkanonen har de dock bärgat från brännaren Jägaren (SMM Fo 86859C).

utses, en som representant för flottan och en för Riksantikvarieämbetet, att följa arbetet med bärgningen av Riksäpplet (Kungl Maj:t Dnr 663).

För flottans vidkommande föll valet på kommendör Lenny Stackell (I875-1957). Han hade tidigare varit inblandad i hanteringen av kanonerna från Riksnyckeln och hyste uppenbarligen ett stort intresse för historia, något som inte minst illustreras av den arkivforskning om Riksäpplet och andra av flottans sjunkna fartyg som han genomfört (fig. 4.2). Tillsammans med Riksantikvarieämbetets konservator E. Sörling skulle Stackell tillgodose statens intressen i samband med bärgningen.

Olschanskis förehavanden på Riksäpplet var uppenbarligen av stort allmänintresse och dagstidningarna hjälpte till att skruva upp förväntningarna redan innan bärgningsångaren stävat iväg mot Dalarö. Från dykeribolagets sida gjordes det ingen hemlighet av att deras plan var att göra en rejäl förtjänst på kanonerna från Riksäpplet. För Stockholms-Tidningen berättar man vad man räknat ut (ST I92I-08-I4): 
Med samma värde som angavs för Vikstenskanonerna, eller cirka I6 ooo kr per styck, kommer man upp till ett bärgningsvärde enbart för bestyckningen på I $280000 \mathrm{kr}$. Därjämte funnes en mängd andra värdefulla inventarier, vapen och ammunition samt en välfylld skeppskassa ombord.

Den 4 september berättar Stockholms-Tidningen: "Riksäpplet med dess 70-80 kopparkanoner och övriga presumtiva dyrbarheter vilar ännu på havets botten [eftersom] de förberedande utrustningsåtgärderna tagit längre tid än beräknat.” Att I60o-talets klockdykare redan bärgat de åtråvärda bronspjäserna var helt och hållet bortglömt vid denna tidpunkt. Lenny Stackell hyser dock misstankar i sådan riktning och påpekar att "man icke med säkerhet vet, vad som upptagits vid tidigare försök" (ST I92I-09-04).

Omsider var dock bärgningsångaren Sigrid på plats och tungdykarna kunde påbörja arbetet. Uppgifter från dessa inledande dykningar ger en fingervisning om vrakets skick när arbetet påbörjades. I motsats till vad som ofta påstås - att skeppet fram till dess var intakt - var det ett kraftigt sargat skrov som mötte dykarna. De olika däcken hade fallit samman och låg ovanpå varandra ( $D N$ I92I-09-22). Så småningom lyckades dykaren lokalisera akterstäven och därmed förstå vrakets orientering. Några kanoner påträffades inte men väl bogsprötet, flera kompletta kanonlavetter med hjul, en krutskyffel och ett tjugotal kanonkulor (ST i92 I-09-06).

Akterskeppet är alltjämt den bäst bevarade delen av skrovet. Så tycks ha varit fallet även när Olschanskis dykare började arbeta på vraket. I Aftonbladet den 9 september I92 I berättas att dykaren "lyckats tränga in i akterrummet, den del av fartyget, där kaptenen och officerarna hade sin bostad", varifrån dykaren bärgat ett blomsterornament och ett fajansfat, "tydligen en pjäs tillhörande fartygschefens servis - vanligt folk åt som bekant på trätallrikar" ( $A B$ I92I-09-09).

Stockholms dykarbolags dykare hade varit inne i Riksäpplets "kokhus". Även Olschanskis imponerades av detta och valde därför att lyfta det till ytan. Enligt dagspressen skulle det "i sin helhet upptagits" (ST I92I-09-27) och forslats till Kastellholmen.

Utifrån nyhetsrapporteringen kan man urskilja en viss frustation över att kanonerna alltjämt lös med sin frånvaro. Olschanski och Stackell höll humöret uppe och resonerade att det "icke är omöjligt, att ett stort antal kanoner fallit över bord redan innan fartyget nått 
den plats, där det nu ligger" (ST I92I-09-I0). De resonerade vidare kring kanonernas tyngd och misstänkte att de brakat långt ner i det söndriga skeppet. Innan de kunde förvänta sig att påträffa några fynd måste de röja undan lösa plankor.

I ett försök att komma åt de kanoner som förmodades ha sjunkit ner i sjöbotten utanför vraket, monterades en mudderskopa ombord på ångaren. Man arbetade sig ner i dyn men det enda hårda material som doldes i djupet var en utlöpare av Äppelskäret ( $S T$ I92I-IO-IO).

I samband med bärgningsarbetet lyckades dykarna även lokalisera vraket efter brännaren Jägaren som sjönk några veckor efter Riksäpplet. Brännaren hade i likhet med Riksäpplet deltagit i sjötåget I676 och tagit sin tillflykt till Dalarö efter nederlaget utanför Öland. Vraket är i allmänhet känt som Gröne Jägaren, men förmodligen kallades det kort och gott Jägaren. ${ }^{8}$ Det är ett mindre fartyg som påträffades på 30 meters djup och visade sig vara väldigt välbevarat. En 3-pundig järnkanon bärgades. Det är framför denna kanon som Lenny Stackell och Leonard Olschanski poserar på bilden 4.2.

Större och mindre delar av Riksäpplets bordläggning bärgades och "visade sig förunderligt väl konserverade, ehuru naturligtvis svartnade genom vattnets inflytande [...]. Även om inga kanoner påträffas, har således bärgaren icke blivit alldeles utan byte" (ST I92I-09-I0). I Stockholms-Tidningen berättas även att "[d]ykaren har dessutom funnit ett mycket stort stycke av bordläggningen, Io meter långt och fyra meter bredt, men detta har ännu icke upptagits" (ibid.). Att ett sammanhängande stycke av bordläggningen skulle vara en anmärkningsvärd upptäckt talar mot att Olschanski själva skulle sprängt sönder skeppet. Det ska snarare läsas som ett uttryck för entusiasm över att de i oredan av lösa skeppstimmer för ovanlighetens skull hittat något med något slags struktur.

Beskrivningen av det sammanhängande partiet bordläggning stämmer ganska väl överens med den lösa del av skrovsidan som påträffats på sex meters djup 50 meter norr om vraket (fig. 3.3). Kanske är det Olschanski som släpat iväg detta parti och lagt det på grunt vatten i väntan på bärgning men sedan aldrig återkommit?

Att det plötsligt ansågs ointressant att bärga skrovsidan bottnar eventuellt $\mathrm{i}$ att företrädarna för Nordiska kompaniet (NK) påpekade att långt ifrån all svartek är något att ha. De menade att svartek naturligtvis var mycket värdefullt, men att möbelfirmor och andra som kommit över sådant i allmänhet hade blivit besvikna. På grund av det 


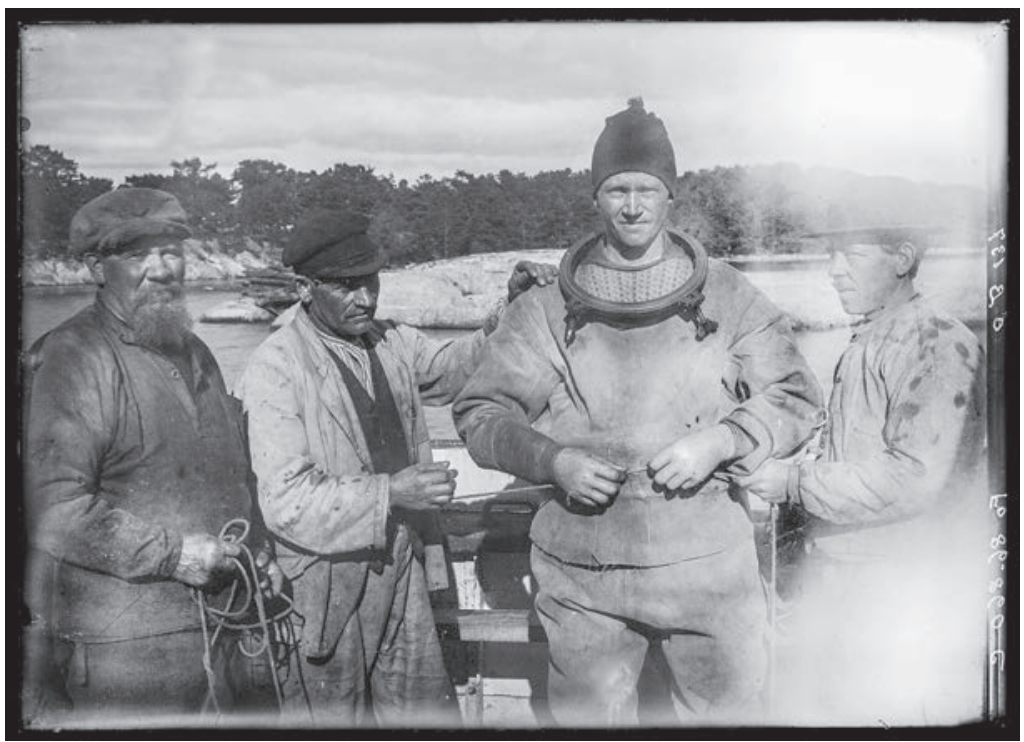

Fig. 4.3. En av Olschanskis dykare gör sig redo att bege sig ner till vraket. Äppelskärets släta granithäll skymtar i bakgrunden (SMM Fo86860C).

stora antalet spik- och dymlingshål är det väldigt lite av varje planka som kan användas för möbeltillverkning ( $A B$ I92I-09-28). Virket från spanten och bordläggningen blev därför i det närmaste ointressant.

Efter Nordiska kompaniets synpunkter om de problem som var förknippade med svartek koncentrerade sig Olschanski på att lyfta de däcksbalkar som burit upp över 80 kanoner och flera hundra människor. I dessa fanns endast ett fåtal dymlings- och spikhål och däcksbalkarna var omkring 40 centimeter tjocka och vissa nära II meter långa. Eftersom de kollapsade däcksnivåerna dessutom antogs dölja eventuella kanoner framstod prioriteringen logisk. Idag finns endast ett fåtal fragment efter däcksbalkar kvar på vrakplatsen.

Det antogs att värdet på virket i däcksbalkarna skulle motsvara mahogny, den merkostnad som svartekens preparering medför borträknad. Det sjödränkta ekvirket ansågs må bra av att ligga i sötvatten tills sältan gått ur. Därefter skulle det indränkas med olja så att torkningen skedde inifrån ( $A B$ I92I-09-30).

Mycket lite är känt kring vad som blev av virket som Olschanski lyfte från vraket. En ofta återberättad anekdot är att virket skulle ha använts till portarna i Stockholms stadshus (se t.ex. Grisell 2009:7, 


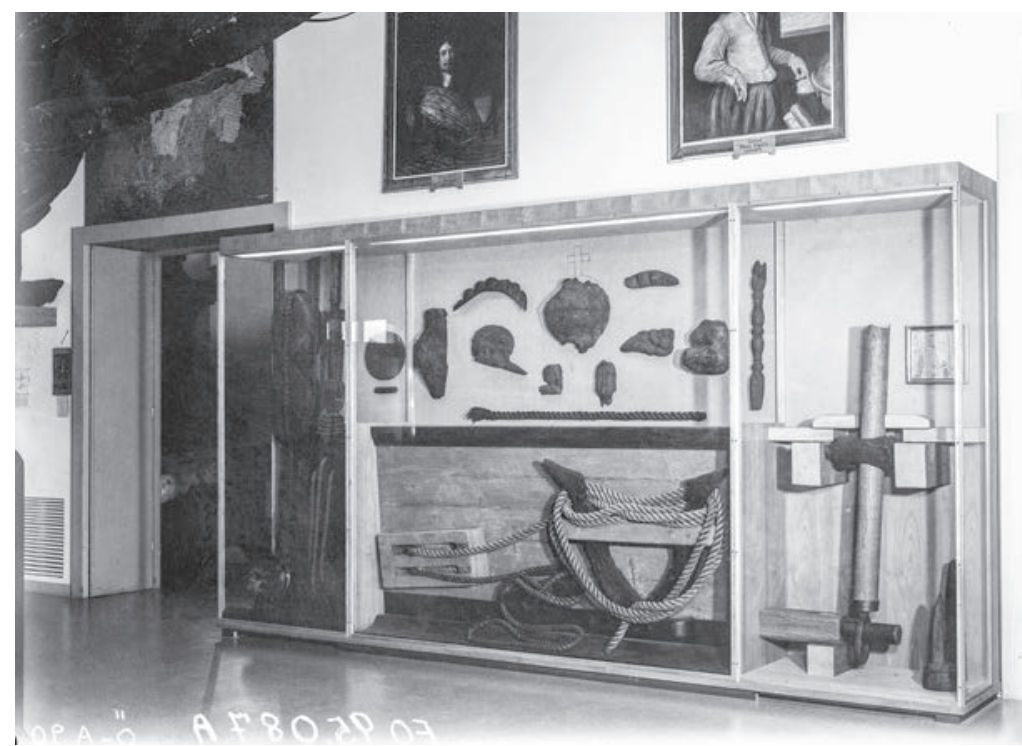

Fig. 4.4. Det så kallade Vasarummet såsom det såg ut när Sjöhistoriska museet slog upp portarna 1938. I montern syns fynd från Riksäpplet i form av skulpturer, block och kollernöten - en del av fartygets styranordning. Notera de två målningarna ovanför montern vilka avbildar en ung Carl Gustaf Wrangel till vänster och Claes Uggla till höger (SMM inventarienummer Fo95087A).

Smirnov 2002:IOI). Arkitekten Ragnar Östbergs gigantiska medeltidspastisch innehåller en uppsjö av listiga historiska anspelningar och kommentarer i sin utformning, något som förankrat Stadshuset i platsens historia redan från början. Byggnaden sammanflätades med huvudstadens förflutna genom ett frekvent återanvändande av delar från äldre numera rivna Stockholmsbyggnader (se t.ex. Östberg 1922).

Att i detta sammanhang stoppa in delar av ett svenskt örlogsfartyg från stormaktstiden måste ha varit mycket tilltalande. Hela porten har dock inte tillverkats av virke från Riksäpplet. Konstnären Lee Spångberg har benat i historien och kommit till slutsatsen att det endast är en mindre del av porten som har förfärdigats av detta exklusiva virke. Stadshuset invigdes I923, två år efter det att virket skulle ha lyfts från botten. Själva porten tillverkades av en firma i Sparreholm medan detaljer på densamma förfärdigades av bildhuggaren Ansgar Almqvist. Förmodligen är det endast Almqvists detaljer som gjorts av virke från Riksäpplet (Spångberg 2013). 
Hur mycket Olschanskis egentligen tjänade på svarteken från Riksäpplet är okänt. Däremot finns uppgifter om att fynd som de sakkunniga valt ut köptes in till statens sjökrigshistoriska samlingar (fig. 4.4). Fynden bytte ägare för 2500 kronor, vilket bara var en bråkdel av utgifterna för bärgningsarbetet. De uteblivna bronskanonerna kom således att stå Dykeribolaget dyrt.

Efter nederlaget såg sig bröderna Olschanski snart om efter andra sjunkna skepp där bronskanoner kunde finnas kvar. Sålunda diskuterade de flera idag välbekanta skeppsnamn såsom Kronan, Svärdet, Resande mannen, Vasa, Nyckeln (i Kalmarsund) och Rikswasa. Men det var för sent. Mot slutet av 1922 gick Dykeriaktiebolaget Olschanski i konkurs (Randall 20I3:40) och verksamheten upphörde.

Intressant nog är de skepp som Olschanskis intresserade sig för strax före konkursen i flera fall identiska med de fartyg som återfinns på Anders Franzén ofta reproducerade vrakkarta (fig. 4.5) (Franzén 1981:36-37, 1982:6-8, 1985:I4-15). Franzén kallar kartan för sitt "Vrakprogram från 1953 som bidrog till att utveckla sportdykning och skeppsarkeologi i Sverige" (Franzén 1977:103). Urvalet av fartyg på kartan är egentligen ganska märkligt och det finns anledning att ifrågasätta utifrån vilka kriterier urvalet har skett. Finns det någon gemensam nämnare för de tolv skeppen?

Franzén säger själv: "Dessa skepp ansåg jag vara av vetenskapligt intresse och åtminstone teoretiskt möjligt att lokalisera" (Franzén I985:I4). En ganska konstig formulering eftersom Riksnyckeln, Riksäpplet och vraket som kallas Gröne Jägaren redan lokaliserats när kartan sammanställdes. Dessutom finns flera kända vrak från de aktuella seklen som inte är med på kartan, såsom exempelvis Elefanten (I564), Nyckeln (I679), Enigheten (I679) med flera skepp, vilka ur vetenskaplig synvinkel torde vara minst lika intressanta. Urvalet på kartan är helt enkelt de skepp som Olschanskis resonerat kring som potentiella objekt att bärga bronskanoner eller andra dyrbarheter ifrån.

Det finns en lös koppling mellan Olschanski och Franzén. Vid bärgningsarbetet år I92 I omkom en av dykarna. Kroppen fördes iland på Dalarö där en sommarboende läkare upprättade dödsattesten och ombesörjde transporten till Stockholm. Som en tacksamhetsgest erhöll läkaren ett bärgat lavetthjul från Riksäpplet. Läkaren var far till Anders Franzén, som i olika sammanhang återkommit till hur gåvan från Olschanski fått honom att reflektera över de speciella förhållanden för bevarande av trä som råder i Östersjön (Franzén I985:13; Grisell 2009:7). 


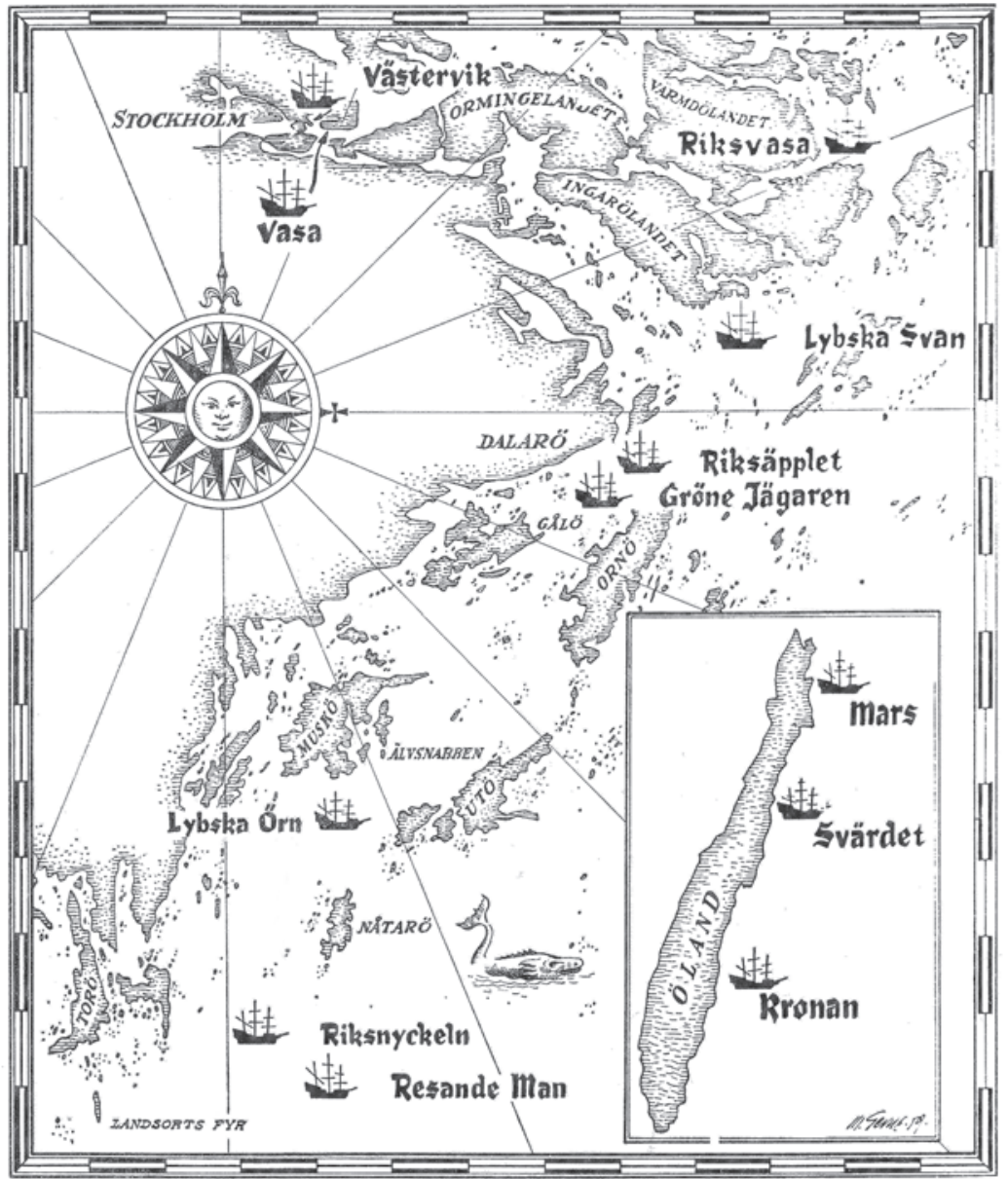

Fig. 4.5. Anders Franzéns så ofta reproducerade vrakkarta återger i stort sett de vrak som Olschanskis och Stackell intresserade sig för. Efter Cederlund \& Hocker 2006:174.

\section{Hamilton, Franzén och Fahlén}

Det var tre nyckelpersoner som återupptog dykningarna på Riksäpplet under 1950-talet. Utöver Anders Franzén var det greve Edward Hamilton (I895-I977), som efter att ha pensionerats från sin position som kommendör blivit chef för örlogsavdelningen vid Sjöhistoriska museet (Cederlund 2006:173-175). Den tredje personen var dykaren Paul Fahlén (I92I-2005). De tre herrarna tog upp tråden där Stackell 
och Olschanski hade lämnat den i början av 1920-talet. Som exempel sökte de med hjälp av dykare, helikopter och vattenkikare efter skeppet Resande mannen vid Gunnarstenarna, försökte återfinna Riksnyckeln, lokaliserade på nytt Gröne Jägaren och lyfte ett antal fynd från Riksäpplet (SSHM Dnr 662/53).

Fahléns bevarade dagbok är en levande skildring av trions sök- och bärgningsverksamhet på sjunkna skepp i Stockholms skärgård. Han var den som genomförde det praktiska undervattensarbetet och beskriver här ett dyk på Riksäpplet (Fahlén, 1954:9):

Precis vid spiselhällen kom jag ner och började titta efter något att ta upp som var av intresse. Massor av lavetthjul såg jag men de var ganska dåliga, jag fick tag på en träbit med ett par uttag på varje sida. Den såg ganska kul ut så jag tog den med mig och sam en runda med den som reserv om jag skulle hitta något bättre. Jag fann inget och gjorde uppstigning. Frasse [Anders Franzén] tog hand om biten och undrade hur "äpplet mådde". Jag dök igen och sökte, hittade som jag trodde, ett mellanstycke till en kanonlavett men det var det inte sa Hamilton när jag kom upp.

Att detta besök knappast var det första på Riksäpplets vrakplats och att de redan tidigare hade bärgat ett antal fynd och trävirke framskymtar i en annan passage: "Vid Sandemars såg stannade vi och Frasse sorterade ut en planka från 'äppelvirket' som han satte en lapp på och skulle hämtas" (ibid.:8).

På 1950-talet formaliserades dykeriverksamheten på Riksäpplet. Den före detta kommendören Hamilton ledde arbetet för Sjöhistoriska museets räkning och tog hjälp av sina kontakter inom flottan för själva dykeriarbetet. Under 1950-talet kom åtskilliga av marinens tungdykare att besöka vraket som en del av sin övning och utbildning. Ett stort antal fynd bärgades vid dessa dykningar och införlivades i museets samlingar (Cederlund 1983:48; 2006:I73-I75), däribland ytterligare en I8-pundig gjutjärnskanon som Olschanskis missade (SMM Inv nr Ö I IOOO). Att den plötsligt påträffades under marinens arbeten skvallrar om att de gjorde ganska betydande ingrepp i lämningen.

Hamilton publicerade även en artikel med titeln "En marinarkeologisk undersökning" i Sjöhistorisk årsbok, där han redogör för arbetet. Artikeln är intressant i disciplinhistoriskt avseende, eftersom det är första gången någon kallar bärgningsaktiviteterna på Riksäpplet för 
arkeologi. Symptomatiskt för dessa tidiga marinarkeologiska undersökningar är emellertid den totala avsaknaden av arkeologer (se även diskussion hos Eriksson 2014a:26-36).

Hamilton uttrycker ganska bestämda åsikter om tidigare verksamheter på vraket och beklagar dess sönderrivna tillstånd (Hamilton 1957:170):

Vraket skulle alltså i dag kunnat giva oss en tydlig bild av dåtida skeppsbyggeri med alla dess konstruktiva detaljer samt även tillfört oss mängder av föremål, som kunde belyst såväl den krigstekniska utrustningen som det dagliga livet ombord om ej vraket genom ansvarslösa sprängningar blivit så hårt spolierat. En första dykning och sprängning företogs nämligen I868, då bl. a. de I8-pundiga kanoner togs upp, som nu kröner vallarna kring Solliden på Skansen. En andra skövling, man kan inte kalla det annorlunda, ägde rum så sent som I92I då en känd skrotfirma erhöll tillstånd att ta upp virke för att sedermera avyttra detsamma som "sjödrucken ek". En av de dykare, som var med vid detta tillfälle, har berättat att man för att komma åt virket, tillverkade stora ramar av läkt å vilka surrades rader av dynamitpatroner, varefter ramarna fästes å fartygssidan och tändes.

Skulden för vrakets sargade tillstånd har här i stor utsträckning fallit på Olschanskis. De pekas ut som de stora bovarna i skövlandet. Det är en uppfattning som även lanserades i olika interna dokument vid denna tid: "Under 1920-talet företog professionella dykare bärgningar på vraket. I detta sammanhang sprängdes det dittills relativt oskadade vraket med tillstånd från berörda myndigheter" (utdrag ur PM rörande SSHM:s åtgärder föranledda av sportdykarverksamhet).

Som påpekats av Lorelei Randall förefaller det emellertid osannolikt att Olschanski sprängt skeppet (2013:25). I tidningsreportage uttalade sig Olschanskis i ganska förvånade ordalag om skeppets sargade tillstånd och spekulerade: "Sannolikt är vrakets förstörelse icke enbart beroende av strandningen, utan det synes även ha blivit utsatt för regelrätt sprängning" ( $A B$ I92 I-09-09). En sådan formulering framstår onekligen som ganska överflödig om Olschanskis själva sprängt skeppet.

Som jag redan påpekat torde Hamiltons vittnesuppgift rörande apteringen av dynamiten, med hjälp av träramar, snarast härröra från I80o-talets bärgningar, eftersom det står utom tvivel att Stockholms dykarbolag nyttjade "det nya krutet" vid sina operationer på I860-talet. 
Före dem hade Hofstädter och Liberton demolerat stora delar av skrovet på mekanisk väg.

Trots att Franzén i princip tog vid där Olschanski slutade, genom att leta efter de skepp som bärgningsfirman valt ut tillsammans med Stackell, så hyste han knappast några högre tankar om bröderna. I en radiointervju från 1980-talet där Franzén talar om Vikstenskanonerna säger han att de bärgades av en "en clown vid Cirkus Orlando vid namn Olschanski" och när han i en artikel berättar om hur bröderna sökt efter skeppet Resande mannen så hänför han dem i raljerande ordalag till "den brokiga skaran extramurala forskare som sökt antropogena bottendeponat" (Franzén 1977:102).

\section{Från fridlysning till lagskydd}

Först 1967 kom skepp som blivit vrak för mer än Ioo år sedan att skyddas från mänsklig åverkan genom kulturminneslagen. Tidigare hade staten andra knep att ta till för att skydda lämningar (se översikt hos Arnshav 20I I). Den I5 september 1956 gav Riksantikvarieämbetet tillstånd till Sjöhistoriska museet att undersöka vraken efter Riksäpplet och det som kallas Gröne Jägaren. I samband med detta fridlystes vraken "intill dess museets undersökning av vraken utförts" (Resolution, Riksantikvarieämbetet Dnr 466/56 även 442:I/56), vilket i praktiken innebar att endast marinens dykare hade tillstånd att besöka vraken. Redan i juli samma år hade dock Hamilton och Franzén för säkerhets skull satt upp en skylt på skäret Äpplet med texten (Minnesanteckningar i SSHMs arkiv, signerade E. Hamilton 1954-06-29, med handskrivet tillägg "Anslaget uppsatt 26.7.1954"):

Obehöriga äga ej taga befattning med härutanför liggande vrak. Vetenskapliga undersökningar pågå.

Statens sjöhistoriska museum.

Att undersökningen av Riksäpplet genomfördes av Sjöhistoriska museet innebar dock i realiteten att det var marinens tungdykare som dök och bärgade där i museets namn. Hur frekvent det gamla regalskeppet fick besök, och vad marindykarna egentligen hade för sig därnere under slutet av I950-talet, är svårt att få någon närmare klarhet i. De uppgifter som finns i museets arkiv består mest av sporadisk korrespondens och listor som upprättats i samband med att museet mottagit olika fynd. 
I den mån någonting hamnat på pränt så är det i samband med fynd av sensationellt slag. Till exempel besökte en amerikansk geolog vid namn dr Robert Dill vrakplatsen tillsammans med svenska marinen I957 och bärgade en skulpterad kvinnofigur ( $S v D$ 1957-07-19).

Åtminstone sedan början av 1960-talet förlade kustartilleriet sin dykarutbildning till vraken utanför Dalarö. Från 196I och framåt finns åtskilliga sammanställningar över fynd från Riksäpplet och Gröne Jägaren som lämnats in till museet. Dokumentation av vrakplatsen och fyndens sammanhang saknas helt och den antikvariska kontrollen tycks ha varit i det närmaste obefintlig.

Till de mer anmärkningsvärda fynden som påträffades hörde en förrådskista. Den bärgades i sin helhet och transporterades till konserveringsanläggningen på Beckholmen, där den grävdes ut. Kistan visade sig innehålla spik och talgljus (SSHM Dnr 2286/67; Expr. 1964-06-03; DN 1964-06-04; 1964-06-I2). Fotografier på Sjöhistoriska museet visar att åtskilliga stora skeppstimmer bärgades från vraket 1967. Vad som därefter skedde med skeppsdelarna är okänt.

Faktum är att det genomgående är sämre ställt med lägesangivelse och dokumentation kring de fynd som lyftes i samband med marinens bärgningar jämfört med Olschanskis. I det senare fallet fanns Lenny Stackell på plats och rapporterade till dagstidningarna om var i vraket bärgningarna skedde. Riksäpplet är alltjämt en komplicerad och svårbegriplig vrakplats, även för ett tränat skeppsarkeologiskt öga. Bruket av tungdykarutrustning har knappast förbättrat situationen eller siktförhållandena under vatten. I rapporten från 1964 berättas att femton dykare deltog i övningen. De gjorde första övningen i par för att hinna orientera sig innan vattnet blev för grumligt. Det råder inga som helst tvivel om att vraket utsatts för betydande påverkan av de tungdykare som i blindo famlat, klivit och halkat omkring bland de hala, uppmjukade skeppstimren.

Sjöhistoriska museet fortsatte samarbetet med marinen under ytterligare ett par år. Under 1968 fördes diskussioner om hur undersökningarna skulle fortsättas. Det var egentligen först nu som förutsättningarna att kartera vrakplatsen började diskuteras på allvar. Som ett steg i denna riktning fanns planer på att upprätta en fotomosaik av förskeppet (SSHM Dnr I891/68). Fotomosaik var en inte helt oprövad metod, den hade praktiserats redan 1964 i samband med undersökningen av ett vrak med arbetsnamnet "Fyrspännaren" som ligger strax norr om Landsort (Cederlund och Löfstrand 1969: I Io). 
Rensningen av vraket påbörjades av elever från flottans dykarskola under 1968 varvid löst "bråte av ointressant slag" lades utanför styrbordssidan. Friläggningen föreslogs fortsätta 1969 men det är osäkert om så skedde.

\section{Civila dykare och arkeologer}

Att kulturminneslagen 1967 utvidgades till att även omfatta skeppsvrak kan på sätt och vis ses som startskottet för en mer professionaliserad marinarkeologi i Sverige. (För en genomgång av lagändringen, se Cederlund 1983:6I-62; Arnshav 20I I:39-44; Eriksson 20I4a:2I-36.) Genom lagskyddet kom sjunkna skepp att omfamnas av en antikvarisk verksamhet på ett annat sätt än tidigare, och tillfälliga juridiska speciallösningar som exempelvis fridlysning blev överflödiga. Som en intressant effekt fick andra grupper tillträde till vrak som Riksäpplet. Vem som helst med sportdykarcertifikat kunde nu få dyka på platsen.

Samtidigt ägnade sig allt fler åt dykning. Den lätta dykutrustningen, eller grodmansutrustningen som den vanligtvis kallades under I960-talet, blev billigare och alltmer spridd. Jacques-Yves Cousteaus filmer och böcker hade skapat en medvetenhet om undervattensvärldens existens. Vasabärgningen i Sverige, undersökningen av Skuldelev-skeppen utanför Roskilde i Danmark och den amerikanske arkeologen George Bass undersökningar av forntida vrak i Medelhavet, hade gett bilden av undervattensvärlden som en veritabel skattkammare. I takt med att fler och fler personer hängav sig åt dykning som hobby, påträffades också ett större antal vrak.

Under ledning av arkeologen Carl Olof Cederlund, som tidigare varit involverad i utgrävningen av Vasa, undersöktes skeppsvrak av intresserade sportdykare, det vill säga privatpersoner. Grupper formerades kring utforskandet av olika vrak under handledning och överinseende av Sjöhistoriska museet och senare även Stockholms universitet (Cederlund 1997; Eriksson 2014a:28-31).

Åren 1972-1973 genomförde en av dessa grupper på eget initiativ och på egen bekostnad en undersökning av Riksäpplet. Ambitionen var i första hand att mäta och fotografera och därigenom samla in material som kunde ligga till grund för en plan över vrakplatsen. De utförde triangelmätning med måttband och fotograferade med stillbildskamera och bärgade även ett antal skulpturer ifrån akterskep- 
pet, vilka jag kommenterar mer ingående i kapitel 7. Dykargruppen gjorde ett mycket noggrant och systematiskt arbete och till skillnad från marinens dykare sammanställde de även skriftliga rapporter som illustrerades med såväl fotografier som skisser.

Dokumentationen från arbetena uppvisar emellertid en del missuppfattningar kring vrakets orientering. I den skissplan som bifogats rapporten ritas en köllinje ut i mitten av vrakplatsen med två symmetriskt placerade rader spant på vardera sidan. En liknande uppfattning kan skönjas i de korthuggna handskrivna anteckningarna från marinens expedition 1968. Där beskrivs hur man påbörjade "rensningen" för att "få en uppfattning om på vilken nivå man befinner sig" (skrivelse från "L. Hallgren", inkommen till Statens Sjöhistoriska museum I969-0203, min kursivering). Här kan man skönja en liknande uppfattning om skrovets orientering. Ingenstans bland de förvisso ganska magra uppgifterna om hur tidigare besökare, röjdykare och grodmän upplevt själva vrakplatsen, finns uttalanden som visar att man insett att skeppet ligger med kraftig slagsida.

\section{De sista svarteksbärgarna}

När sportdykning blev populärt under i960-talet var den svarta eken fortfarande eftertraktad och attraktiv. Den siste som storskaligt lyfte det exotiska vattendränkta trävirket ur djupet var dykaren Sven Nahlin. Han är mest förknippad med bärgningen av skeppet Rikswasa som sjönk vid Djurö I623 och som han i mitten av I960-talet lyfte i delar för att sälja som souvenirer till "dollarturister", som det hette på den tiden. Det paradoxala är att medan Nahlin slet Rikswasa i stycken ute vid Djurö pågick som bäst undersökningen, konserveringen, rekonstrueringen och utställningen av skeppet som fick överta Rikswasas namn. Det skepp vi idag vanligtvis känner som regalskeppet Vasa var i full färd med att nå sin position som nationalmonument.

Sven Nahlin blev något av en kändis på kuppen, inte som en skändande marodör som rev kulturarvet i stycken utan som en äventyrare, företagare och entreprenör. Den pietet som idag visas lämningar från I6oo-talet oavsett om de består av vrak på havets botten, byggnader, möbler eller annat, var långt ifrån självklar vid denna tidpunkt. Här tål att påminnas om den sorgliga demoleringen av de så kallade Klarakvarteren i Stockholms innerstad som pågick parallellt med Nahlins härjningar på Rikswasa. 
Reportage om Nahlins bedrifter förekom såväl i Sveriges Television som i dagstidningar och i veckopress som Hemmets veckojournal och FIB-aktuellt. Där framställdes hur den dykande företagaren gjorde stora pengar på så kallad svartek (reportage finns i tidskriften $S e$ den I962-09-I0; Hemmets Veckotidning 1969 nr 4I; DN I964-04-09; I965-05-08; Expr. I964-04-I2; I964-OI-2I; I964-02-28; I964-0225, FIB-aktuellt 1963-I2-I6; 1965-0I-26). Att kulturminneslagen år I967 ändrades till att även omfatta skeppsvrak anses ibland vara en direkt följd av Nahlins framfart på Rikswasa (Cederlund 1983:6I-62; Arnshav 20II:39-44). Tillägget i kulturminneslagen kallas ibland skämtsamt lex Nahlin.

Åren efter att tillägget vunnit laga kraft övervakades att det verkligen efterföljdes. I Sjöhistoriska museets vrakregister finns åtskilliga rapporter från bland annat kusttullmästaren på Dalarö som vittnar om både febril dykverksamhet och myndighetsmässig vaksamhet. Enligt företrädare för myndigheterna opererade dykarna i skydd av mörkret och bärgade vrakdelar.

Måndagen den 23 juni 1975 upptäckte kustbevakningen under en patrull en motorbåt med tre personer som avgick från Riksäpplets vrakplats. Båten prejades och i den fanns självaste Sven Nahlin - Rikswasas bärgare - och på durken låg två bitar svartek, båda omkring I,2 meter långa. Svarteksbitarna var dock inte lyfta till ytan för att bli souvenirer, utan för att tjäna ett annat ganska originellt syfte. Nahlin var inte bara entreprenör med svarteksförsäljning utan även dykinstruktör och de bärgade vrakdelarna skulle vara rekvisita i samband med att en av hans elever skulle examineras, nämligen kung Carl XVI Gustaf.

Besök av medlemmar ur kungafamiljen tenderar att noggrant arrangeras och regisseras. Svarteksbitarna på durken i Nahlins båt skulle tvättas av och snyggas till inför kungens dykning. Dyiga och slemmiga skeppstimmer belamrade av musslor, dy och havstulpaner skulle lämpa sig dåligt på bild tillsammans med den i dykarutrustning utstyrde monarken.

Examensprovet genomfördes två dagar senare och enligt dagspressen var Nahlin "mycket imponerad av kungens prestationer". Nahlin utbildade även blinda dykare och med sig ner till Riksäpplet hade kungen förutom Nahlin den blinda Annika Larsén. Nere på vraket spikade kungen upp en bronsplakett med texten "Hans Majestät Carl XVI Gustaf inspekterade Riksäpplet den 25 juni 1975" och när han återvände till ytan hade han med sig en av de finputsade svartekspinnarna. 
Kusttullmästaren på Dalarö polisanmälde hovet och Nahlin för fornminnesbrott eftersom de inte hade ansökt om tillstånd att göra ingrepp i vraket. Kungen är immun men Nahlin fick en reprimand innan ärendet lades ner. Ekbitarna släpptes tillbaka på vraket så snart pressfotograferna lämnat platsen ( $S v D$ 1975-06-26; 1975-06-29; Expr. I975-06-28; Raä Dnr 4I28/75; SSHM Dnr I432/75; KBV Dnr 283/75). Vad som hände med den uppspikade bronsplaketten är okänt.

Blåsvädret kring Riksäpplet fick dock inte kungen att tappa intresset för dykning och skeppsvrak. När Kronan påträffades utanför Öland var han i vattnet igen och sedan dess är han till och med Kronanprojektets beskyddare (se t.ex. Einarsson 2016:170-I7I). I olika sammanhang har han också återkommit till hur han personligen fiskat upp mynt från Kronans vrakplats (DI 200I-05-II) och så sent som härom året besökte han undersökningen av skeppet Mars, som också förlist utanför Öland.

Det kungliga dyket på Riksäpplet är intressant också ur en annan synvinkel. Dykinstruktören Annika Larsén var nämligen mig veterligen den första kvinna som dök på vraket. När Svenska Sportdykarförbundet grundades 1958 fanns enstaka kvinnor med och vid mitten av I960-talet fanns även enstaka kvinnliga dykinstruktörer, enligt vad marinarkeologen Staffan von Arbin muntligen berättat. Detta gällde dock inom den civila dykningen. Fram till 1967 var Riksäpplets vrakplats fridlyst och tillträde således förbehållet marinen, vilket innebar att det i realiteten uteslutande var män som dök på vraket.

Den manliga dominansen inom marinarkeologin har påtalats $\mathrm{i}$ olika sammanhang (se Ransley 2005:62 I-629). När marinarkeologen Catharina Ingelman-Sundberg skrev en bok om sina egna erfarenheter om att verka i branschen gav hon den titeln Bland hajar, karlar och vrak. Att utbilda yrkesdykare var länge förbehållet marinen (jfr Ingelman-Sundberg 1995:60) och oftast genomfördes denna utbildning som en del av värnplikten.

\section{Sportdykarnas Riksäpplet}

Även om Riksäpplet inte finns i det allmänna medvetandet på samma sätt som Vasa eller Kronan, så är det ganska välkänt bland sportdykare. Riksäpplet är ett av de vrak i Stockholms skärgård som besökts av flest dykare. Detta ska dock inte nödvändigtvis förstås som att dykare är mer intresserade av historia än vad folk i gemen är. De frekventa besöken på Riksäpplet har helt andra orsaker. 
Många av de företag som erbjuder dykcharter i Stockholms skärgård har sin hemmahamn på eller i närheten av Dalarö. Under en vanlig dagsutfärd görs ofta minst två dyk. Av dykmedicinska skäl genomförs det djupaste först. Detta djupare dyk utgör oftast utfärdens huvudnummer, eftersom de mer intakta vraken ligger lite djupare och längre ut i skärgården där siktförhållandena i vattnet ofta är lite bättre. När dykarna återvänder till ytan från ett sådant dyk är de mättade av det kväve som ansamlats i kroppens vävnader. De måste därför vistas på ytan en viss tid innan det är säkert att bege sig ner i djupet igen. Utfärdsbåten brukar vända hemåt och nalkas Dalarö skans och Äppelskäret lagom till att överskottskvävet vädrats ut. Anledningarna till att Riksäpplet ofta får besök av dykare är således snarare topografiska än kulturhistoriska.

De flesta dykare upplever dessutom vraket som ganska ointressant. En genomläsning av de loggböcker som dykare lagt upp på internetsidor visar att det mest minnesvärda från dykplatsen ofta varit de stim av abborrar som uppehåller sig kring de spridda skeppsdelarna, den starka strömmen eller någon liten malör som inträffat när de befunnit sig under vattnet.

Riksäpplet har således brutits ner kontinuerligt sedan förlisningen, av I60o-talets sågande och brytande för att man skulle komma åt bronskanonerna, av den första sprängningen och av I800-talets mer industriellt betonade och effektiva demolering med hjälp av tungdykare och dynamit. Att skeppet trots sprängningar, bärgningar, strömmar, oaktsam ankring, sportdykning och andra aktiviteter alltjämt är ett av världens bäst bevarade krigsfartyg, byggt enligt de under I600-talet högt ansedda engelska principerna, är en av den svenska marinarkeologins bäst bevarade hemligheter. 